\title{
REVIEW ON SPREAD OF PARASITIC HARD TICKS ON FIELD ANIMALS IN IRAQ
}

Zainab A. Makawi , Suhad Y. Jassim \& Khalida I. Hasson

Iraq Natural History Research Center and Museum, University of Baghdad, Baghdad Iraq.

*Corresponding author: zainabalwan540@yahoo.com

\begin{abstract}
This study focused on many kinds of ticks distributed in Iraq and on various kinds of domestic and wild animals, and the distributed of ticks affected by the environment such as temperature and humidity, and to identify the diseases caused by ticks where the vertebrates are exposed to many diseases and inflammatory and allergic reactions as a result of a tick bite containing toxins in the saliva of the tick, which causes paralysis and lead to death, authors were able to review most of the local and international studies related to Tick's diagnosis (classification), especially tick species distribution in Iraq. Aim of this study was to create a database and put an important reference for all researchers and authors who plan to study this field more comprehensively in the future .
\end{abstract}

keywords: Tick, species , Ixodes, larve, Iraq. 


\section{Introduction}

Tick infestations result in a loss of almost 3 billion hides of livestock (Chmela et al., 2016). Ticks transfer pathogen to host bloodstream from their bowel through their saliva (Karim et al.,2017). Ticks transmit a variety of pathogens to vertebrate hosts, including humans, domestic and wild animals, including viruses, bacteria, and protists. These pathogens cause many diseases of the virus (e.g. CrimeanCongo hemorrhagic fever, West Nile fever, Omsk hemorrhagic fever, and Colorado tick fever, microbial diseases (Lyme disease, $Q$ fever, borreliosis, and relapse fever), fungus diseases (dermatophilosis), protozoal diseases (theileriosis and babesiosis), and rickettsial diseases (anaplasmosis, ehrlichiosis, Brazilian spotted fever, and Rocky Mountain spotted fever.( Bente et al., 2013; Pujalte and Chua,2013; Chmela et al.,2016).

\section{Classification of Tick}

Ticks are compulsory ectoparasites that feed on blood from their hosts. Ticks belong to the Arthropoda phylum, Arachnida class,Acari subclass, Parasitiform order and Ixodida suborder (Estrada-Pena et al., 2010). Three tick families are classified as Ixodidae (hard ticks), Argasidae (soft ticks), and Nuttalliellidae (restricted Tanzania and South Africa) (Shi et al.,2018). More than 900 tick species have been classified by the world. Ticks not only lead to physical damage through blood sucking and skin wound to their hosts, but some of these tick species always have the ability to transmit pathogens to their host. The tick prevalence in any region depends on various variables such as climate, predators and competitor species. (Bartikova et al.,2017).

\section{Species}

The Ixodidae family consists of 14 genera and 704 species and is generally divided into Prostriata (the Ixodes genus alone) and Metastriata (all other family genera). This classification is based on morphological (i.e. anal groove collocation compared to anus) and biological characteristics (Walker et al., 2003). There are 5 genera and 195 species in the Argasidae (Guglielmone et al., 2010). They include comprise the most genera and species of greatest medical and veterinary concern (Jongejan and Uilenberg, 2004).

\section{Life cycle of tick}

There are four distinct phases in the tick life cycle: egg, larva, nymph and adult. The adult phase with male and female sexes is characterized by sexual dimorphism (Walker et al., 2003). A single gravid female can produce several hundred to thousands of globular eggs, generally brown, before dying in the environment Oviposition lasts for several days (Sonenshine, 1991). Depending on the tick species and the climatic conditions, eggs can hatch between two weeks to several months after laying. Each viable egg gives origin to a six-legged (i.e. hexapod) larva. When hatched from their respective eggs, larvae begin to seek a host to feed on for a long time depending on the biological characteristics of each species (Sonenshine, 1991). Larvae consume their blood meal after feeding and moult into an eight-legged (i.e., octopod) nymph, In addition to larvae, stigmata and tracheal structures have been developed in tick nymphs and adults, making them more vulnerable to desiccation than the developmental stage of hexapod (Needham and Teel, 1986). Nymphs will also feed on a vertebrate host for several days after moulting (i.e. 4-8) before moulting into the next adult developmental stage (Sonenshine, 1991). Adults ticks are sexually competent. Mating can happen off the host in the setting for prostriate ticks (genus Ixodes), while it happens only on the host for metastriates, generally at the same time as blood feeding (Sonenshine, 1991). The engorged, fertilized woman falls off the host after mating and moves through the surroundings in search of an appropriate oviposition site. According to the number of individual hosts on which they feed on throughout their life cycle (Figure.1), ticks can be classified as:

*One-host ticks: food and moulting of the same animal, parasitized by the larval stage of the tick. The species of the Boophilus subgenus of the genus Rhipicephalus provide an example of one-host ticks ; their life cycle can be completed within a few weeks (Walker et al., 2003).

*Two-host ticks: during their cycle, parasitize two animals: one as larvae and the other as adults. Therefore, larva and nymph happen in the same host. After feeding to moult in the environment, the engorged nymph drops off the host. Then it would parasitize the resulting adult and feed on another host. Rhipicephalus evertsi is a typical instance of a two-host tick in Africa that parasites cattle (Walker et al., 2003). 
*Three-host ticks: Three distinct animals, one for each growth stage, are parasitized. All three-host tick moults in the virtual environment can be detected. The life cycle of a three-host tick is considerably longer than that of one-host ticks (Walker et al., 2003).

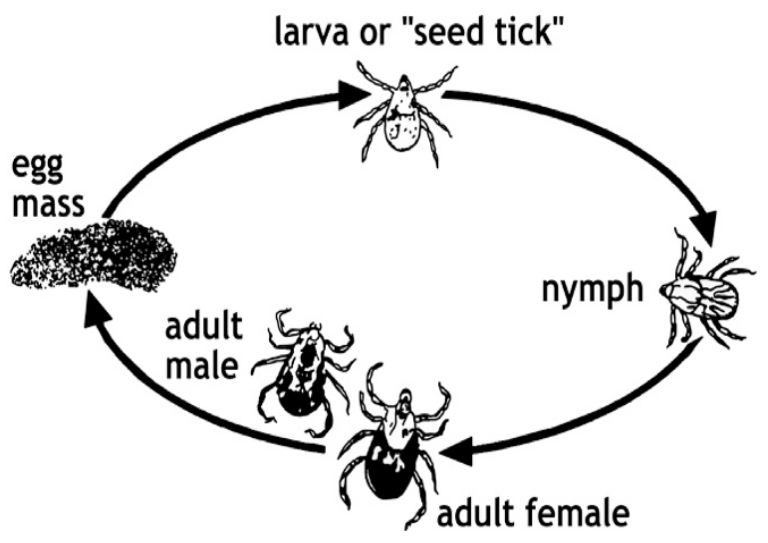

(Fig.1) Life cycle of tick

source:

http://medent.usyd.edu.au/fact/ticks.htm

\section{Isolation of Tick}

The selected ticks put in a mixture of $70 \%$ ethanol with few drops of glycerin while the remaining ticks were combed on a white rug soaked with cypermethrin, then all dropped ticks were counted and burned. . The specimens were identified steromicroscopically according to (Soulsby, 1982). Adult arthropods and larvae were cleaned in cooked $10 \%$ $\mathrm{NaOH}(\mathrm{aq})$; or lactophenol at room temperature for distinct times, installed by Canada balsam between the slide and cover slip, which was put in 40c. Hard mounting medium oven for a few days (Apanaskevich et al.,2008).

\section{Pathogenicity of Tick}

Ticks can vertically transfer several pathogens to their descendants of the larval stage, which can then be transferred to the nymph and then to the adult. Thus contagious state can be maintained over several generations without contact with a vertebrate reservoir. The vector capacity of ticks changes between species and particular pathogens is sometimes transferred by a limited range of ticks only (Diaz, 2010 ).
Tick bites can cause a range of adverse reactions in regards to infectious diseases, ranging from localized pain and inflammation to severe allergic reactions such as anaphylaxis or tick paralysis. Tick paralysis caused by a toxin found in saliva. Holocyclus is a common cause of animal paralysis and death, and although it is uncommon today, it was deadly to the developers in humans (Chris et al.,2011)

\section{Review in the previous studies Distribution} of Hard Tick species in different area of Iraq.

Distribution of ticks on hosts affected by multiple variables such as tick morphology (hypostome length), host morphology (fur coat length) (Pfaffle et al., 2013). Vatsya et al.(2007) related to host immune sponses, self-grooming, inter-specific relationships, heat-dissipating behaviour and feeding phase duration. So far as seasonal abundance is concerned, the results showed a significant distinction among the months in the number of tick collections. Tick abundance and distribution rely on many indicators, including environment (temperature, moisture, sunlight, wind acceleration and dust) (Patel et al 2012). Host nature (susceptibility, gender, age, and sex) and management procedures including acaricide use. Tick species ' seasonal dynamics are the result of suitable environmental circumstances, temperature, moisture, light intensity, and rainfall (Gray, 1991; Das, 1994). The occurrence of ticks with restricted movements can be significantly impacted by the chances of encountering a prospective host and their densities of population. The variation in the distribution of ticks in various seasons of the year is based on a multitude of factors such as climatic circumstances, host lifestyle and habitat characterization. (Dantas-Torres, 2010 ; Kwak, 2014; Gonzalez et al.,2017). Temperature is the main extrinsic factor of incidence of ectoparasites because it controls the metabolic rate and affects both the effectiveness of the use of blood-meal, the length of periods of oviposition and the rate of development, relative humidity is the controlling factor of water balance mechanisms of ticks. Low humidity is a major stress on tick water balance and appears to have an adverse effect on the effectiveness of converting the blood meal into egg biomass. (Chabra et al., 1983; Labruna et al.,2002). 
AL-Fatlawi et al ., (2008) ) recognizing the 50 tick species obtained from infested cattle skin in Al-Najaf provence. While in Aldoura region south Baghdad recorded infested with tick was $27.8 \% \quad$ (Hasson ,2012 ). AlRammhi,(2013) recorded two tick species ; Rhipicephalus turanicus and Rhipicephalus leporis with burden average $61.14 \%$ in AlQasim district-Babylon province. Hasson and Al-Zubaidi, (2014) recorded prevalence of cattle ticks infestation $91.3 \%$ in Wasit province districts. While Al-dulimy and Alamery, (2015) recorded the chicken were infested with one tick species (Argas persicus), in a whole rate of $17.22 \%$ in Baghdad province .

\section{Conclusion}

The spread and identification of different types of hard ticks in different regions of Iraq. authors were able to review most of the local and international studies related to Tick's diagnosis (classification), especially tick species distribution in Iraq.

\section{References}

Apanaskevich ,D.A. Schuster, A. L. and Horak, I. G. (2008). The Genus Hyalomma: VII. Redescription of all parasitic stages of $\mathrm{H}$. (Euhyalomma) dromedarii and $\mathrm{H}$. (E.) schulzei (Acari: Ixodidae) . J. Med. Entoml. Vol.45(5):pp817-831.

AL-Fatlawi, M.A.A. Ali M.J. and Albayati, H.H.(2018). Morphological and phylogenetic study of Hyalomma anatolicum in Al-Najaf, Iraq, Iraqi Journal of Veterinary Sciences, Vol. 32, No. 2, 2018 (261-266).

Al-dulimy E. J F and Alamery, A. M. A (2015) . Isolation and diagnosis of the ectoparasites of house chickens in the province of Baghdad and study their effects on the blood, Qadisiyah Journal of Veterinary Medicine Vol. 14 Issue (1);1-6.

Al-Rammhi , H. M , Mohammad Mohammad, KM and Mohammad, H( 2013). TICK INFESTATION OF HARES (LEPUS CAPENSIS) IN ALQASIM DISTRICTBABYLON, IRAQ. Euphrates Journal of Agriculture Science-5 (1): 8-14.

Bartíková $P$, Holíková $V$, Kazimírová $M$, Štibrániová I (2017). Tick-borne viruses. Acta Virologica:;61(04):413-427.
Bente DA, Forrester NL, Watts DM, McAuley AJ, Whitehouse CA, Bray M. Crimean-Congo. (2013). hemorrhagic fever: History, epidemiology, pathogenesis, clinical syndrome and genetic diversity. Antiviral Research.;100:159-189.

Chmelăr J, Kotál J, Kopecký J, Pedra JH, Kotsyfakis M (2016). All for one and one for all on the tick-host battlefield. Trends in Parasitology.;32:368-377.

Chabra MB, Ruprah and S.K. Gupta.(1983) .Ixodid ticks on bovines in Haryana: A preliminary report.Cherion.; 12:298-303.

Chris P. LowbridgeA, Stephen L. DoggettB and Stephen GravesC (2011). Tickborne diseases ,NSW Public Health Bulletin Vol. 22(11-12) .

Das SS(1994). Prevalence of ixodid ticks infestation on farm animals in Pantnagar, tarai of Uttar Pradesh. JParasit. Appl.Anim. Biol.; 3:71-73.

Dantas-Torres F (2010). Biology and ecology of the brown dog tick, Rhipicephalus sanguineus. Parasites and Vectors.;3:26-35.

Diaz JH (2010). Ticks, including tick paralysis. In: Mandell, Douglas and Bennett's principles and practice of infectious diseases. Mandell GL, Bennett JE and Dolin R, editors. Philadelphia: Elsevier;. p. 3649-62.

Estrada-Peña A, Mangold AJ, Nava S, Venzal JM, Labruna MB, Guglielmone AA (2010). A review of the systematics of the tick family Argasidae (Ixodida). Acarologia.;50(3):317333.

Gray JS (1991). The development and seasonal activity of the tick Ixodes ricinus: A vector of Lyme borreliosis. Med. Vet. Entomol. 79:323-333.

Gonzalez I, Labruna M, Chagas CR, Salgado P, Monticelli C, Morais LH et al (2017). Ticks infesting captive and freeroaming wild animal species at the São Paulo Zoo, São Paulo, Brazil. Braz. JVet. Parasitol., Jaboticabal; 26(4):496-499.

Guglielmone AA, Robbing RG, Apanaskevich DA, Petney TN, Estrada-Peña A, Horak IG, Shao R, Barker SC (2010) The Argasidae, Ixodidae and Nuttalliellidae (Acari: Ixodida) of the world: a list of valid species name. Zootaxa. 2528: 1-28. 
Hasson R.H (2012). Tick distribution and infestation among sheep and cattle in Baghdad's south suburb, Kufa Journal For Veterinary Medical Sciences Vol. (3) No. (1).

Hasson, R.H and Al-Zubaidi, H.H (2014). Cattle and buffaloes tick's infestation in Wasit province districts, IraqKufa Journal For Veterinary Medical Sciences Vol. (5) No. (1); 31-40.

Jongejan F, Uilenberg G (2004) The global importance of ticks. Parasitology.129: 3S-14S.

Karim S, Budachetri K, Mukherjee N, Williams $\mathrm{J}$, Kausar A, Hassan MJ, et al. A study of ticks and tick-borne livestock pathogens in Pakistan. PLoS Neglected Tropical Diseases. 2017;11(6).

Kwak YS, Kim TY, Nam SH, Lee Y, Kim HP, Mduma S, et al (2014). Ixodid Tick Infestation in Cattle and Wild Animals in Maswa and Iringa, Tanzania. Korean J Parasitol;52(5):565568.

Labruna M, De Paula C, Lima T, Sana D (2002). Ticks (Acari: Ixodidae) on Wild Animals from the Porto-Primavera Hydroelectric Power Station Area, Brazil. Mem. Inst. Oswaldo Cruz, Rio de Janeiro.; 97(8):1133-1136.

Needham GR, Teel PD (1986) Water balance by ticks bloodmeals. In: Morphology, Physiology and Behavioral Biology of tick. Edited by Sauer JR, Hair JA. Ellis Horwood Ltd, Chichester, UK, pp. 100-104.

Pujalte GGA and Chua JV (2013). Tick-borne infections in the United States. Primary Care; Clinics in Office Practice.;40:619-635.

Pfaffle M, Littwin N, Muders SV, Petney TN (2013). The ecology of tick-borne diseases. International Journal of Parasitology.; 43:1059-1077.

Patel G, Shanker D, Jaiswal AK, Sudan D, Verma SK. Prevalence and seasonal variation in ixodid ticks on cattle of Mathura district, Uttar Pradesh. J Parasit. Dis., DOI Buffalo Bulletin. 2012; 34(1).

Sonenshine DE (1991) Biology of ticks. Vol. 1. Oxford University Press, New York, U.S.A.
Shi J, Hu Z, Deng F, Shen S (2018). Tickborne viruses. Virologica Sinica.;33(1):21-43.

Soulsby, E. J. L. (1982). Helminths, Arthropods and Protozoa of Domesticated animals. 7th Edition, London.

Vatsya S, Yadav RR, Kumar R, Garg S (2007). Seasonal activity of Boophilus micropluson large ruminants at an organized livestock farm. J Vet. Parasitol.; 21(2):125-128.

Walker AR, Bouattour A, Camicas JL, EstradaPeña A, Horak IG, Latif A, Pegram RG, Preston PM (2003) Ticks of domestic animals in Africa, A guide to identification of species. Bioscience Reports, Edinburgh, U.K.

Walker AR, Bouattour A, Camicas JL, EstradaPeña A, Horak IG, Latif A, Pegram RG, Preston PM (2003) Ticks of domestic animals in Africa, A guide to identification of species. Bioscience Reports, Edinburgh, U.K.

Elmer Gray (May 16, 2012). The University of Georgia .Circular 937 Retrieved from http://medent.usyd.edu.au/fact/ticks.htm 